\title{
Globalization, Inequality, and Transnational Activism: A Case Study on Chile
}

\author{
Moctezuma Garcia
}

\begin{abstract}
Globalization has transformed how states are governed through a neoliberal economic approach that reinforces an unregulated capitalist market. An emphasis on Chile is important because it was the first state in Latin America to apply neoliberalism and has been hailed as a prime example for other developing states to integrate similar strategies to strengthen the local economy. However, inequality continues to persist despite economic gains. A combination of historical struggles affecting victims of the Pinochet era and present struggles with poverty, have resulted in a constant conflict between the power elite and the rest of society. Social movements in Chile have played a pivotal role in raising international awareness and pressuring the local government to protect the rights of highly vulnerable populations. A focus on transnational activism provides an effective medium for local and international advocates to work together toward holding Chile accountable for addressing social disparities.
\end{abstract}

Keywords: Globalization, inequality, human rights, transnational activism, Latin America, social movements

[G]lobalisation is a multi-dimensional process characterized by:

- the acceptance of a set of economic rules for the entire world designed to maximise profits and productivity by universalizing markets and production, and to obtain the support of the state with a view to making the national economy more productive and competitive;

- technological innovation and organisational change centred on flexibilisation and adaptability;

- the expansion of a specific form of social organisation based on information as the main source of productivity and power;

- the reduction of the welfare state, privatisation of social services, flexibilisation of labour relations and weaker trade unions;

- de facto transfer to trans-national organisations of the control of national economic policy instruments, such as monetary policy, interest rates and fiscal policy;

- the dissemination of common cultural values, but also the re-emergence of nationalism, cultural conflict and social movements. (Urzúa, 2000, pp. 421-422)

Globalization in the 1990s reinforced a neoliberal economic model that fostered an unregulated capitalist system (Kotz, 2002) that transformed how states are governed.

Moctezuma Garcia, Ph.D., LSW, is a Postdoctoral Teaching Associate, Central Michigan University, Department of Sociology, Anthropology, and Social Work.

Copyright (C) 2013 Advances in Social Work Vol. 14 No. 1 (Spring 2013), 13-25 
States are no longer able to function in isolation, which requires one to take into consideration the influence that internal and external factors have on implementing economic strategies at the state level. "States find themselves trying to respond to pressures from local societies and global markets simultaneously without the breathing room previously offered by controls on national trade, finance, and production” (Ó Rian, 2000, p. 188). Held and McGrew (2007) indicate that "...national governments across the globe have been forced to adopt increasingly similar (neoliberal) economic strategies which promote financial discipline, deregulation and prudent economic management" (p.55). The national state still has the capacity to influence local markets' involvement with the global economy, but this depends on how government resources are disseminated (e.g., tax incentives, policies) among local entrepreneurs (Ó Rian, 2000).

Globalization further determines how high-income states financially support initiatives to address social disparities in low- and middle-income states, a process that allows the donor states to reinforce their ideology on the recipient states. "Global institutions such as the World Bank and the International Monetary Fund are blatantly pursuing the interests of western governments and impose structural adjustments on poor nations with devastating consequences" (Ife, 2007). The U. S. government, for example, has invested billions of dollars of foreign aid through the President's Emergency Plan for AIDS Relief (PEPFAR) and significant strides have been accomplished in addressing HIV/AIDS globally. But the program has been scrutinized due to contractual agreements for partner states to reinforce abstinence-based interventions for young people and the eradication of prostitution. The Brazilian National AIDS Commission rejected \$40 million from the United States Agency for International Development (USAID) due to the PEPFAR stipulation that excluded sex workers from accessing HIV prevention services (Middleberg, 2006). Brazil, however, is an exception and has taken drastic measures to ensure access to HIV prevention and treatment services for its citizens, which has revolutionized global initiatives addressing HIV/AIDS in low- and middleincome states. An emphasis on foreign aid demonstrates how a hierarchy of power is reinforced and limits the power of recipient states, which may also increase the vulnerability of historically oppressed and highly marginalized populations that are dependent on the local power elite to accept the terms of foreign aid or demand revisions to address issues affecting highly vulnerable populations. Globalization contextualizes the role of the social worker and determines how ideology influences the development of local and international policies that may narrow a professional's ability to address social disparities.

This manuscript focuses on the influence globalization has on reinforcing inequality and how transnational activism can be used as a model for activists to demand accountability from a local government. Chile is used as a focal point, but inequality in Latin America is also discussed to conceptualize how power and status are reinforced between, as well as within, states. The historical perspective on Chile highlights how economic, political, and social events have influenced the development of a nation. A section on transnational activism provides a useful model for social workers to mobilize efforts locally, as well as abroad, to advocate for highly vulnerable populations. Implications for social welfare will also be discussed. 


\section{Inequality in Latin America}

The power elite is composed of men whose positions enable them to transcend the ordinary environments of ordinary men and women; they are in positions to make decisions having major consequences (Mills, 1956, pp. 3-4).

Mills (1956) believed that power is not solitary, but it is composed of an intricate hierarchy put in place to dominate society. Power results in a limited number of power elite members imposing their beliefs and values (ideology) onto the larger society. The power elite are composed of a small percentage of society that controls and determines how, and within what limits, resources (e.g., money, property, education, healthcare) will be disseminated in society. Inequality is based on the uneven distribution of resources throughout society (Hoffman \& Centeno, 2003). Several measures have been used to determine levels of human development and inequality. The Human Development Index (HDI) measures the national level of human development based on health, education, and income (United Nations Development Programme [UNDP], 2011). However, in 2010 the Inequality-adjusted HDI (IHDI) was introduced to take into account differences in human development within a state due to inequality (UNDP, 2011). The HDI and IHDI range from 0 (lowest) to 1 (highest) for determining the level of human development. The GINI index is a measure used to determine levels of inequality based on the distribution of income or consumption within a state, 0 indicates perfect equality and 100 indicates perfect inequality (The World Bank Group, 2012a). Measures to collect data on these indices are limited and restrict greater analyses of inequality, which further impedes our understanding of the phenomenon in Latin America and the Caribbean (Mahoney, 2003). Despite limitations, researchers have been able to utilize measures to determine the influence of the global economic market and levels of inequality between, as well as within, states.

Latin America has a high level of inequality with the top 10\% controlling between 40 to $47 \%$ of the total income (de Ferranti, Perry, \& Ferreira, 2004). Brazil was the only state in Latin America that ranked in the top 10 states with the most billionaires, of which $1 \%$ of that population is worth $\$ 300$ billion (CNBC, 2012). The richest man in the world is Carlos Slim Helu, a citizen of Mexico with a net worth of $\$ 69$ billion (Forbes, 2012). Sebastián Piñera is an established billionaire who was elected president of Chile in 2010 (Meyer, 2012). The United States had 3 of the top 10 richest men in the world (Forbes, 2012). The top $1 \%$ of total income controls $43 \%$ of the wealth in the nation; and the next $4 \%$ control an additional 29\% of the wealth in the United States (Dunn, 2012). Held and McGrew (2007) indicate that “...globalization enhances the development prospects of states in the South and contributes to making the world a less unequal place” (p. 80). Overall, inequality between states has declined from 1978 through 1998 (Firebaugh \& Goesling, 2004). However, the UNDP (2011) demonstrates that greater access to wealth does not lead to a reduction of inequality within a state as demonstrated in the United States (.91 HDI, .85 IHDI, 40.8 GINI), Mexico (.77 HDI, .59 IHDI, 51.7 GINI), and Brazil (.72, HDI, .52 IHDI, 53.9 GINI).

Multiple factors (e.g., employment, education, housing) affect inequality, but it is important to acknowledge the historical context that has influenced the development of a 
nation. Political, economic, and social structures reinforce inequality in Latin America (de Ferranti et al., 2004). States have played a regressive role in providing public goods (e.g., education, health, water, sanitation) for poverty stricken populations (de Ferranti et al., 2004). The power elite in Latin America have the essential resources to protect themselves and influence the state to establish policies that protect their interests (de Ferranti et al., 2004). Historically, social structures were created and maintained to reinforce the interests of the dominant group (e.g., colonizers, power elite), which has resulted in "truncated systems" that exclude the most vulnerable (de Ferranti et al., 2004). "Wealthy groups again have greater options for either exerting influence on public service provisioning for themselves or opting out for private provision" (de Ferranti et al., 2004, p. 123). Scholars (de Ferranti et al., 2004) emphasize that in order for change to occur in Latin America, it must be made from within as well as outside of social structures.

Chile provides a unique perspective because it was the first state in Latin America to apply the neoliberal model in the 1980s to improve its local economic market, which continues to be sustained. Chile is regarded as an upper-middle-income developing state and it has been a strong ally of the United States in advancing democracy, human rights, and trade (Meyer, 2012). Chile's poverty rate has drastically declined since 1990, and no other state in Latin America has been able to approach Chile's progress. Despite Chile's decline in poverty, it still has to overcome obstacles associated with inequality. Chile has become the leader of human development (.81 HDI and .65 IHDI) in Latin America, but ranks number six for the greatest inequality (52.1 GINI) in Latin America (UNDP, 2011). Chile's share of the top $20 \%$ in total income is $57.7 \%$, and its share of the bottom $20 \%$ of total income is 4.3\% (The World Bank Group, 2012b). The distribution of wealth within a state provides critical insight on how power is established and reinforced throughout the years among a select privileged group of an elite upper class.

\section{A Brief Historical Perspective on Chile}

Chile initially established a stable democratic political regime from 1932 to 1970 (Meyer, 2012). Economic development after World War II set the stage for the foundation of the global market. The United States had gained control of power in the world and the Soviet Union threatened American capitalism with communism (Hite \& Roberts, 2007). The United States wanted to secure their status and modernization theory provided an explanation as to why some countries are poor and underdeveloped. “...[A]ccording to this group of 'modernization theorists,' poorer nations are poor because they lack big capital, technology, and modern social organization and values" (Hite \& Roberts, 2007, p. 8). The Soviet Union also had a strong interest in reinforcing socialism in Latin America, and Chile was no exception. Chile encountered significant economic struggles that caused a considerable political shift from a democratic to a socialist state in 1970 .

By the early 1970s, Latin American economies were in trouble. Chile elected the Marxist president Salvador Allende. Allende's solution was not less government intervention, but more. Businesses were nationalized or expropriated. Price 
controls were imposed. Civil unrest grew as the economy spun out of control. (Yergin \& Cran, 2003)

Allende's efforts during his presidential term (1970-1973) to nationalize the state's control of resources backfired and instead united capitalists, landowners, and the middle class to strengthen a political alliance against laborers, peasants, and leftist organizations (Silva, 1993). Disparities increased in Chile and social protests demanded change. This resulted in a military coup and dictatorship by General Augusto Pinochet in 1973 (Garretón, 2005; Yergin \& Cran, 2003).

Pinochet secured his newfound role of the state by conducting a massacre of Allende supporters and prohibiting political protests (Yergin \& Cran, 2003). The military regime seized acquired wealth (e.g., money, property) from middle to upper class families so they would not threaten Pinochet's newly established role, which caused them to transition into poverty (Paley, 2001). Prominent Chilean activists fled the country, and grassroots organizations went underground to avoid tyranny from the military (Paley, 2001). "Indeed, Pinochet's autocratic system of one-man rule had concentrated power at the top to such a degree that it seemed as if the state had developed virtually complete autonomy from all social groups” (Silva, 1993, p. 526).

Inflation continued to escalate, as Harberger states in an interview (Yergin \& Cran, 2003): "After a year, year and a half of military government, you still had 20 percent permonth built-in inflation that wouldn't go away until something structurally changed." Significant changes needed to be made and reduction of the state led Chile toward a "[d]ecentralization and privatization with a geopolitical view of power" (Garretón, 2005, p. 364). A small group of elite Chilean scholars, referred to as the "Chicago Boys" who studied free market economic theories abroad at the University of Chicago, influenced Pinochet to take drastic measures through "shock treatment" and apply neoliberalism to stabilize the economy (Yergin \& Cran, 2003).

USAID had established financial support for students from the Catholic University of Chile to study at the University of Chicago and for professors from the University of Chicago to teach economics at the Catholic University of Chile (Borzutzky, 2005). Professor Milton Friedman from the University of Chicago mentored the Chicago Boys and he played an influential role in the development and implementation of the neoliberal economic plan for Chile (Silva, 1991). The Chicago Boys emphasized that “...government decisions were to be inspired by 'technical and scientific' principles and not by political ideological postulates as in the past” (P. Silva, 1991, p. 393). Chile's economic crisis allowed the Chicago Boys to implement a radical alternative, but Pinochet also perceived it as an opportunity to save the country from Marxism (Borzutzky, 2005). The local economic market was completely revamped, which resulted in significant reductions in government budgets and privatization of state-owned businesses (Yergin \& Cran, 2003).

The transition toward an authoritarian regime, implementation of neoliberalism, and globalization of the economy created a new environment for the power elite to maneuver and protect their capital. The neoliberal economic market placed an emphasis on the free market, which gave rise to a new power elite referred to as "technocrats" who were 
highly educated and occupied influential roles in the public and private sectors (Silva, 1991). Pinochet relied on technocrats to secure Chile's economy, but his dependence on others weakened his control of the state. The newly established power elite prospered and became an influential source toward developing state policy under authoritarian rule (E. Silva, 1993). As the power elite became established, the weaker upper-middle class either fled the country or the military sequestered their resources.

Chile encountered an economic boom between 1976 and 1981, but it caused poor people to endure greater inequality (Yergin \& Cran, 2003). Pinochet imposed a new constitution in 1980 to extend his dictatorship for an additional eight years (Yergin \& Cran, 2003). However, a bank crisis from 1981 to 1984 caused widespread protests, which resulted in the organization of civilians to become more critical of the existing regime (Meyer, 2012). The newly established technocrats seized the opportunity and withdrew their support of Pinochet. The Pinochet regime encountered pressures internally (social movements) as well as externally (United States and United Kingdom) to legalize a re-election in 1989, which resulted in Pinochet's defeat and Chile's return to a democratic state (Yergin \& Cran, 2003).

Patricio Aylwin was elected president in 1990 and played an instrumental role in transitioning Chile's return to a democratic state. The significant transition in the economy for Chile during this period was that the state did not allow a completely free market. Garretón (2005) indicates that Chile applied a "[m]arket-oriented model with corrections to the role of the state and policies against poverty" (p.363). The free market allowed Chile's economy to prosper, but inequality rose as well. A combination of liberal trade (import and export) policies and state interventions allowed Chile to overcome international economic struggles and stay ahead of the competition. "Although Chilean exports surged in the 1980s as the peso devalued, they also surged in the early to mid1990s as international prices for nontraditional crops declined markedly and the peso appreciated" (Kurtz, 2001, p. 7). Chile implemented the necessary infrastructures to address local market failures and support local businesses to capitalize on the global market, but a greater emphasis was placed on dynamic sectors such as forestry and fishing (Kurtz, 2001). At the same time, the state provided limited support to the fruit industry, which was distinguished by severe class biases and oligopolies (Kurtz, 2001).

The post 1989 period focused on establishing a democratic state and reducing inequality. The neoliberal economic model increased wealth for Chile, but without state intervention, the rich got richer and the poor got poorer. President Eduardo Frei RuizTagle's (1994-2000) political campaign emphasized rule by the people and not the military, but in 1980 Pinochet enforced a law that ensured life long positions (10 out of 48 seats) in the Senate for military officials (Freedom House, 2007). President Frei RuizTagle's attempts to take power away from the military limited his capacity to implement drastic measures to address social disparities. President Ricardo Lagos Escobar (20002006) focused his initiatives on eliminating poverty, but political corruption charges (peddling, insider trading, and kickbacks) were made public (Freedom House, 2007). Increased rates of unemployment and inflation during Lagos Escobar's presidential term also added to the growing disparities among poverty stricken populations. Chileans grew restless due to limited access to resources and growing levels of inequality. While 
successors of Pinochet encountered the difficult task of maintaining an economic model that would work to stabilize the local economy, it widened economic disparities between the rich and poor in the absence of state intervention. Unfortunately, the top military commanders also proved to influence political initiatives despite Pinochet's defeat in 1989.

In 2006, Chile made history and elected its first female president, Michelle Bachelet (Freedom House, 2007). Inequality persisted and became the force for Chileans to demand government support despite Chile's drastic poverty reduction by 2006. Bachelet was committed to addressing inequality and issues affecting women such as access to healthcare and discrimination against women (Freedom House, 2007). However, Chile's capital surplus in copper increased by 83\% from 2005 to 2006 . Economic gains remained among the wealthy, which spurred social movements demanding distribution of the copper surplus for social programs by students, copper miners, health care workers, and teachers (Freedom House, 2007). In spite of Bachelet's work on inequality, students mobilized in 2006 and pressured the state to increase funding for education (Freedom House, 2007). Chileans also advocated for an increase in salaries and access to their share of the copper boom (Freedom House, 2007). Bachelet demonstrated her commitment to addressing inequality and invested billions towards health, housing, and education for low-income families (Freedom House, 2007).

Despite Bachelet's initiatives to address social disparities, persistent inequality and dissatisfaction with the existing government resulted in a shift of political parties in the 2010 elections from the center-left to the current center-right (Meyer, 2012). However, Chileans continued to protest over gas prices, environmental issues, education, and labor rights (Meyer, 2012). "Some analysts believe Chileans have resorted to street protests as a result of their increasing dissatisfaction with the country's political class, which they view as unresponsive to citizen demands and unwilling to address the country's high level of inequality” (Meyer, 2012, p. 7).

The Pinochet era overall exposed Chilean society to a tumultuous environment that provided a limited sense of safety and security, unless one was directly associated with the military regime. Reestablishment of a democratic government increased vigilance among the public to become more critical of the political system, especially among political leaders responsible for governing the state. Society played a pivotal role in holding the power elite accountable for their actions as well as designating limitations on harnessing wealth and/or resources. Inequality became more prevalent and the public raised awareness through social protests as a vehicle to advocate for the needs of highly disenfranchised populations. Social protests also allowed the local public to raise international awareness on social issues impacting a state locally and provide a global forum to scrutinize initiatives taken by the power elite. Global consumers were able to support causes abroad through financial support of local grassroots organizations or by pressuring their local government to respond to social disparities in another state (e.g., Chile), which is the premise of transnational activism. 


\section{Transnational Activism}

Globalization has not only affected the economy, it has also influenced how people interact. Technology (e.g., Internet, faxes, international flights) has made the world highly accessible, which has revolutionized social activism. The Pinochet era, for example, caused exiled Chileans to mobilize abroad and they played a significant role in raising international awareness of human rights violations due to the Pinochet regime. Foreign human rights organizations gained a greater understanding of the atrocities committed by the Pinochet regime, which garnered international support (e.g., foreign aid, publicity) for local organizations that advocated for social justice and pressured their local government to address claims of human rights violations.

Social activism has transcended borders and it is no longer isolated to a state. Keck and Sikkink (1998) refer to this intricate network between domestic and international actors as "transnational advocacy networks." Tarrow (2005) emphasizes the importance of distinguishing globalization from internationalism. Globalization is grounded in "...a source of interest, ideology, and grievances" (Tarrow, 2005, p. 19). "Internationalism is the institutional and informal framework within which transnational activism - some of it aimed at globalization but much of it independent of that process - takes shape" (Tarrow, 2005, p. 19). Therefore, transnational activists utilize internationalism as a framework to strategize and mobilize toward a designated mission.

Transnational activism has a greater influence on getting the state to address issues due to its endogenous (rooted cosmopolitans) and exogenous (transnational activists) influences. Rooted cosmopolitans are deeply entrenched in a state and play a critical role domestically in activism at the community level (Tarrow, 2005). Transnational activists are a subgroup of rooted cosmopolitans with a deep understanding of issues at the state level who become key actors in raising awareness and support at the international level (Tarrow, 2005). The link between transnational activists (e.g., Chilean exiles) and rooted cosmopolitans (e.g., Chilean activists during the Pinochet era) determines how influential the transnational network will be on pressuring the government to address social disparities.

Transnational networks usually arise due to a lack of response by the state on issues being raised by local activists. Keck and Sikkink (1998) identified the following tactics to pressure a state to respond: 1) information politics - generates information quickly to impact the political climate and persuade people to act, 2) symbolic politics - relates the lived experience of the people encountering human rights violations for people abroad to join the alliance, 3) leverage politics - encourages powerful actors in influential positions to withhold resources for the state to respond to the claims of human rights violations, and 4) accountability politics - powerful actors are held accountable for prior commitments and/or policies addressing human rights. Successful transnational networks have committed actors who are influential as grassroots activists and transnational activists. They raise global awareness of the plight of vulnerable populations at the local level and utilize foreign resources (e.g., foreign aid, policy, international trade, media) to pressure a state or local government to address human rights violations. 
Chile, as a case study, highlights how transnational networks are able to persuade, socialize, and pressure the local government to address human rights violations. Amnesty International (2008b) conducted a research mission in 1973 to investigate human rights allegations (i.e., information politics) and collect testimonials of victims (i.e., symbolic politics). Families of victims sought legal support from Spain and the United Kingdom due to failed attempts within Chile to prosecute perpetrators of human rights violations (Pion-Berlin, 2004), which is an example of leverage politics. "In 1978 the military had decreed for itself a sweeping amnesty which let all state security officials off the hook for human rights crimes committed between September 1973 and March 1978” (Pion-Berlin, 2004, p. 483). Amnesty International (2008a) was the first international NGO to pressure the British government to extradite Pinochet during his stay in the United Kingdom in September 2008. Extraditing Pinochet was a paramount moment because international experts (e.g., legal advocates, human rights activists, scholars) were able to successfully raise global awareness and prosecute offenders of crimes against humanity (Pion-Berlin, 2004). External pressures from Spain and the United Kingdom resulted in accountability politics, which influenced Judge Guzman to introduce a "new doctrine" in Chile's judicial proceeding that overturned amnesty of military officials (Pion-Berlin, 2004). Chile's Supreme Court honored the "new doctrine" and was successful in prosecuting multiple military officials guilty of human rights crimes (Pion-Berlin, 2004). Overall, human rights violations committed by the Pinochet regime have caused Chile to create an Institute of Human Rights and designate an under-secretariat for human rights to address complaints from the public as well as organizations (Meyer, 2012). Amnesty International continues to monitor human rights violations in Chile, and attention has currently been focused on prisoners and indigenous people.

\section{Conclusion}

The international field of social welfare requires professionals to take an interdisciplinary approach toward advocating for the protection of highly vulnerable populations. Inequality between states has decreased through globalization, but it is imperative that professionals deepen their understanding of how inequality is reinforced within a state and the affect it has on addressing the needs of highly vulnerable populations. The literature has emphasized the implications of neoliberal ideology being reinforced through globalization, which sustains a hegemonic structure that hinders the distribution of wealth and access to resources. However, every state varies on how a nation is governed and what type of ideology reinforces cultural beliefs and values. Acknowledgement of historical events provides critical insight into how social structures reinforce power and status within a state, as well as political influence between the host and foreign state.

The field of social work takes a multi-perspective approach toward addressing social problems at the micro-meso-macro levels (The Office of the High Commissioner for Human Rights [OHCHR], 1994). Social workers are well poised to address global disparities because the profession reinforces a holistic approach in ensuring social justice, human rights, and sustainable development for highly vulnerable populations. As stated by the National Association of Social Workers (2012): “The primary mission of the 
social work profession is to enhance human wellbeing and help meet the basic human needs of all people, with particular attention to the needs and empowerment of people who are vulnerable, oppressed, and living in poverty.”

The greatest obstacle to overcome in establishing a transnational network is for there to be a consensus of a shared vision and values among activists. Developing a shared vision with an overarching goal and designated objectives is pivotal for the transnational network to be successful in addressing issues and optimizing resources toward accomplishing outcomes. The Universal Declaration of Human Rights (UDHR) provides a common understanding of shared values for key players at every level. The code of ethics for social work also reinforces the UDHR. The Office of the High Commissioner for Human Rights (2012) provides 388 translations of the UDHR and identifies voluntary commitments and pledges made by a state to address human rights. The Millennium Development Goals (MDGs) is an agreement made by states throughout the world to address: 1. Poverty and Hunger; 2. Education; 3. Gender Equality; 4. Child Health; 5. Maternal Health; 6. HIV/AIDS; 7. Environmental Sustainability; and 8. Global Partnerships (United Nations, 2010). The UDHR, along with the MDGs, provide critical tools for activists to collaborate with intergovernmental organizations, international organizations, and local organizations to hold a state accountable for human rights violations and measure progress toward addressing social disparities.

Once a transnational network agrees on a shared mission of designated goals and objectives, it is also important to take into consideration the influence that power, status, and entitlement have within the network as well as external factors between the host and visiting state. Ife (2007) has raised awareness on the implications of globalization and how power has influenced the social work profession in reinforcing a western ideological approach in addressing social disparities abroad. An emphasis is placed on a dominant colonial discourse and the implications it has in shaping the social work profession toward addressing the needs of historically oppressed and highly marginalized populations (Ife, 2007). Professionals addressing social disparities in foreign states must take into account how personal factors (e.g., citizenship, employment status, educational status, biological sex, ethnicity, economic status) influence interactions with the local community as well as the power elite. Foreign professionals should empower rooted cosmopolitans (local activists) to take the lead in addressing local social issues as well as to recognize experiential knowledge as a valuable source for addressing the needs of highly vulnerable populations. A focus on sustainable development strengthens a collaborative approach among activists and prevents the rooted cosmopolitans (local activists) from depending on transnational activists (foreigners) to address the needs of the local community.

An emphasis has been placed on addressing social disparities abroad, but professionals are able to apply the same principles locally to hold a government accountable for reinforcing inequality and social disparities among historically oppressed populations such as Latinos. The UDHR applies to issues within the United States and American ideology continues to influence the development of low- and middle-income states through international aid and policy. Transnational activism utilizes power and status between states to pressure a local government in addressing human rights 
violations among highly vulnerable populations. Therefore, professionals addressing social disparities play a critical role in monitoring existing systems to ensure that the needs of highly vulnerable populations are addressed appropriately. Inequality will remain rampant, unless professionals advocate for change from within as well as from outside existing social structures, domestically and internationally.

\section{References}

Amnesty International. (2008a). Chile: Amnesty International and the Pinochet case.

Retrieved from http://www.amnesty.org/en/news-and-updates/news/five-jailed-chileten-years-after-pinochet-arrest-20081016

Amnesty International. (2008b). Chile: Testimoninals of victims of the Pinochet government. Retrieved from http://www.amnesty.org/en/library/asset/AMR22/005/2008/en/3158201c-9c48-11ddb0c5-35f205e84de0/amr220052008eng.html

Borzutzky, S. (2005). From Chicago to Santiago: Neoliberalism and social security privatization in Chile. Governance: International Journal of Policy, Administration, and Institutions, 18(4), 655-674.

CNBC. (2012). Countries with the most billionaires. Retrieved from http://www.cnbc.com/id/49174052/Countries_With_the_Most_Billionaires?slide=3

de Ferranti, D., Perry, G. E., \& Ferreira, F. (2004). Inequality in Latin America: Breaking with history? Washington, DC: World Bank. Retrieved from http://wwwwds.worldbank.org/servlet/WDSContentServer/WDSP/IB/2004/06/22/000160016_2 0040622141728/Rendered/PDF/28989.pdf

Dunn, A. (2012, March 21). Average America vs. the one percent. Forbes. Retrieved from http://www.forbes.com/sites/moneywisewomen/2012/03/21/average-americavs-the-one-percent/

Firebaugh, G., \& Goesling, B. (2004). Accounting for the recent decline in global income inequality. American Journal of Sociology, 110(2), 283-312.

Forbes. (2012). The world's billionaires. Retrieved from http://www.forbes.com/billionaires/

Freedom House. (2007). Freedom in the world - Chile. Retrieved from http://www.unhcr.org/refworld/docid/473c55b849.html

Garretón, M. A. (2005). Social sciences and society in Chile: Institutionalization, breakdown and rebirth. Social Science Information, 44(2-3), 359-409.

Held, D., \& McGrew, A. (2007). Globalization/anti-globalization. Malden, MA: Polity Press.

Hite, A., \& Roberts, J. T. (2007). Development and globalization: Recurring themes. In J. T. Roberts \& A. Hite (Eds.), The globalization and development reader: Perspectives on development and social change. MA: Blackwell Publishing. 
Hoffman, K., \& Centeno, M. A. (2003). The lopsided continent: Inequality in Latin America. Annual Review of Sociology, 29, 363-390.

Ife, J. (2007). The new international agendas: What role for social work? Inaugural Hokenstad International Social Work Lecture, San Francisco. Retrieved from http://ifsw.org/statements/the-new-international-agendas-what-role-for-social-work/

Keck, M. E., \& Sikkink, K. (1998). Activists beyond borders: Advocacy networks in international politics. New York: Cornell University Press.

Kotz, D. M. (2002). Globalization and neoliberalism. Rethinking Marxism, 12(2), 64-79.

Kurtz, M. (2001). State developmentalism without a developmental state: The public foundations of the "free market miracle" in Chile. Latin American Politics and Society, 43(2), 1-26.

Mahoney, J. (2003). Long-run development and the legacy of colonialism in Spanish America. American Journal of Sociology, 109(1), 50-106.

Meyer, P. J. (2012). Chile: Political and economic conditions and US relations. Congressional Research Service. Retrieved from http://www.fas.org/sgp/crs/row/R40126.pdf

Middleberg, M. I. (2006). The anti-prostitution policy in the US HIV/AIDS program. Health and Human Rights, 9(1), 3-15.

Mills, C. W. (1956). The power elite. NY: Oxford Press.

National Association of Social Workers. (2012). Code of ethics Retrieved from http://www.naswdc.org/pubs/code/code.asp

Ó Rian, S. (2000). States and markets in an era of globalization. Annual Review of Sociology, 26, 187-213.

Office of the High Commisioner for Human Rights [OHCHR]. (1994). Human rights and social work: A manual for schools of social work and the social work profession. Geneva, United Nations Publications. Retrieved from http://www.ohchr.org/Documents/Publications/training1en.pdf

Paley, J. (2001). Marketing democracy: Power and social movements in post-dictatorship Chile. Berkeley: University of California Press.

Pion-Berlin, D. (2004). The Pinochet case and human rights progress in Chile: Was Europe a catalyst, cause or inconsequential? Journal of Latin American Studies, 36(03), 479-505.

Silva, E. (1993). Capitalist coalitions, the state, and neoliberal economic restructuring: Chile, 1973-88. World Politics, 45(4), 526-559.

Silva, P. (1991). Technochrats and politics in Chile: From the Chicago Boys to the CIEPLAN Monks. Journal of Latin American Studies, 23(2), 385-410. 
Tarrow, S. (2005). The new transnational activism. New York, NY: Cambridge University Press.

The World Bank Group. (2012a). GINI index. Retrieved from http://data.worldbank.org/indicator/SI.POV.GINI

The World Bank Group. (2012b). Income share held. Retrieved from http://data.worldbank.org/indicator/SI.DST.05TH.20/countries

U.S. Department of Education. (2012). National center for education statistics. The Condition of Education 2012. Retrieved from http://nces.ed.gov/fastfacts/display.asp?id=16

United Nations Development Programme. (2011). Human development report. Retrieved from http://hdr.undp.org/en/statistics/hdi/

United Nations. (2010). We can end poverty 2015: Millenium Development Goals. Retrieved from http://www.un.org/millenniumgoals/bkgd.shtml

Urzúa, R. (2000). International migration, social science, and public policy. International Social Science Journal, 52(165), 421-429.

Yergin, D., \& Cran, W. (2003). The commanding heights: The battle for the world economy. Retrieved from http://www.pbs.org/wgbh/commandingheights/lo/index.html

\section{Author note:}

Address correspondence to: Moctezuma Garcia, Ph.D., LSW, Postdoctoral Teaching Associate, Central Michigan University, Department of Sociology, Anthropology, and Social Work, 142 Anspach, Mount Pleasant, MI 48859 Email:

moctezuma.phd@gmail.com 